\section{Loyalitas Kreativitas \\ Aldi Masyarakat Kreatif}

P-ISSN 2722-2101, E-ISSN 2722-4201

Program Studi Ekonomi Manajemen Universitas Pamulang Jurnal LOKABMAS Kreatif Vol. 01, No. 03, Hal. 106-111

Email:jurnalkreatif.manajemen@gmail.com

\title{
KIAT MANAJEMEN KEUANGAN DALAM MENGHADAPI KRISIS ATAU SITUASI YANG TIDAK TERDUGA SEPERTI PADA MASA PANDEMI COVID-19
}

\author{
Ratna Dumilah, Munarsih, Welly Indra, \\ Ernawati Suwarno, Irenne Putren. \\ Dosen Ekonomi Fakultas Ekonomi Manajemen Universitas Pamulang \\ Email dosen02209@unpam.ac.id, dosen02448@unpam.ac.id, dosen02528@unpam.ac.id, \\ dosen02533@unpam.ac.id, dosen01820@unpam.ac.id
}

\begin{abstract}
ABSTRAK
Tujuan dari Kegiatan Pengabdian Kepada Masyarakat adalah untuk melaksanakan salah satu Tri Dharma Perguruan Tinggi. Selain itu adalah untuk meningkatkan keterampilan berfikir para remaja di Rumah Pintar dalam kiat manajemen keuangan dalam menghadapi krisis atau situasi yang tidak terduga seperti pada masa pandemi Covid-19..

Metode dalam pelaksanaan kegiatan pengabdian kepada masyarakat yang digunakan adalah curah pendapat dan diskusi. Teknik dalam pelaksanaan kegiatan pengabdian kepada masyarakat yang digunakan adalah kerja kelompok dengan jumlah peserta 15 (lima belas) orang remaja peserta didik di Rumah Pintar Kota Tangerang Selatan.

Adapun luaran dari kegiatan pengabdian kepada masyarakat ini berupa publikasi artikel pada media massa cetak dan online dan satu artikel ilmiah yang dipublikasikan melalui Jurnal Lokabmas PKM Universitas Pamulang, serta peningkatan pengetahuan, pemahaman dan keterampilan para remaja peserta didik di Rumah Pintar Tangerang Selatan tentang kiat manajemen keuangan dalam menghadapi krisis atau situasi yang tidak terduga seperti pada masa pandemi Covid19.
\end{abstract}

\section{Kata Kunci: Kiat Manajemen Keuangan, Krisis, Pandemi Covid-19}

\begin{abstract}
ABSTRAC
The purpose of Community Service Activities is to carry out one of the Tri Dharma of Higher Education. In addition, this is to improve the thinking skills of teenagers in Rumah Pintar in financial management tips in dealing with crises or unexpected situations such as during the Covid-19 pandemic. The method used in implementing community service activities is brainstorming and discussion. The technique in implementing community service activities used is group work with 15 (fifteen) teenage students at Rumah Pintar, Kota Tangerang Selatan.

The output of this community service activity is the publication of articles in print and online mass media and one scientific article published through the PKM Lokabmas Journal, Pamulang University, as well as an increase in the knowledge, understanding and skills of young students at Rumah Pintar South Tangerang regarding financial management tips. in the face of crises or unexpected situations such as during the Covid-19 pandemic..
\end{abstract}

\section{Keywords: Financial Management Tips, Crisis, Covid-19 Pandemi}

\section{PENDAHULUAN}

Pada 2 Maret 2020, untuk pertama kalinya pemerintah mengumumkan dua kasus pasien positif Covid-19 di Indonesia. Namun, Pakar Epidemiologi Universitas Indonesia (UI) Pandu Riono menyebutkan virus corona jenis 


\section{Loyalitas Kreativitas \\ Aldi Masyarakat Kreatif}

P-ISSN 2722-2101, E-ISSN 2722-4201

Program Studi Ekonomi Manajemen Universitas Pamulang Jurnal LOKABMAS Kreatif Vol. 01, No. 03, Hal. 106-111

Email:jurnalkreatif.manajemen@gmail.com
SARS-CoV-2 sebagai penyebab Covid-19 itu sudah masuk ke Indonesia sejak awal Januari.

"Sejak awal Januari kemungkinan besar virus (SARS-CoV-2) itu sudah masuk ke Indonesia," kata Pandu dalam diskusi daring bertajuk "Mobilitas Penduduk dan Covid-19: Implikasi Sosial, Ekonomi dan Politik" pada Senin (4/5/2020).

Pandemi Covid-19 ternyata dapat dengan cepat berdampak pada keuangan rumah tangga. Termasuk resolusi keuangan 2020 yang telah disusun sebelumnya, menurut seorang analis. "Memasuki tahun 2020 lalu, banyak dari kita yang telah menentukan resolusi keuangan untuk tahun ini, apakah mulai menabung secara berkala, melunasi utang secara bertahap, dan lain-lain. Namun, tanpa diduga datang pandemi Covid-19, yang ternyata dapat dengan cepat berdampak pada keuangan rumah tangga," kata Head of Investment Specialist PT Manulife Aset Manajemen Indonesia (MAMI), Freddy Tedja, dalam keterangannya di Jakarta, Selasa (26/5).

Hasil Survei Nasional Literasi Keuangan 2019 menunjukkan bahwa berdasarkan gender, indeks literasi dan inklusi keuangan perempuan yaitu sebesar $36,13 \%$ dan $75,15 \%$ masih lebih rendah dibanding indeks literasi dan inklusi keuangan laki-laki yaitu masing-masing sebesar 39,94\% dan 77,24\%.

Menurut Ketua Yayasan Allianz Peduli, Ni Made Daryanti, keberadaan anak muda yang termasuk generasi Z (Gen Z) tidak bisa dikesampingkan karena berpengaruh besar terhadap perekonomian negara. Namun sayangnya, gaya hidup saat ini membuat banyak generasi muda lebih memilih menghabiskan pendapatan mereka untuk hal-hal yang sedang tren, atau mengikuti prinsip 'you only live once' (YOLO) dan 'fear of missing out' (FOMO). "Perlu adanya edukasi untuk para Gen $\mathrm{Z}$ tentang cara mengatur dan mengontrol keuangan secara smart, mempertimbangkan kebutuhan jangka panjang, serta memberi inspirasi untuk mulai berkarya agar stabil secara finansial," ujarnya.

Demi terwujudnya para remaja putra dan putri yang merupakan calon ibu dan calon bapak menjadi remaja yang berpengetahuan, berkompentensi dalam keterampilan dan memiliki akhlak yang baik dan berdasarkan analisis situasi tersebut diatas, pengusul bersama mitra yaitu Rumah Pintar Yatim dan Dhuafa Al Ikhlas Tangerang sepakat mengusung tema "Kiat Manajemen Keuangan dalam Menghadapi Krisis Atau Situasi yang Tidak Terduga Seperti pada Masa Pandemi Covid-19".

\section{RUMUSAN MASALAH}

Berdasarkan latar belakang diatas, maka dapat rumusan masalahnya adalah Bagaimana kiat manajemen keuangan dalam menghadapi krisis atau situasi yang tidak terduga seperti pada masa pandemi Covid-19 pada remaja peserta didik di Rumah Pintar Yatim dan Dhuafa Al Ikhlas Tangerang ?

\section{TUJUAN PELAKSANAAN}

Tujuan pada kegiatan pengadian kepada masyarakat ini adalah untuk meningkatkan keterampilan berfikir dalam manajemen keuangan dalam menghadapi krisis atau situasi yang tidak terduga seperti pada masa pandemi Covid-19 pada remaja peserta didik di Rumah Pintar Yatim dan Dhuafa Al Ikhlas Tangerang.

\section{TINJAUAN PUSTAKA}

Menurut Kamus Besar Bahasa Indonesia (KBBI), arti kiat adalah akal (seni atau cara) melakukan. Arti lainnya dari kiat adalah taktik. Menurut Agus Sartono (2001:6) Manajemen keuangan dapat diartikan sebagai manajemen dana baik yang berkaitan dengan pengalokasian dana dalam berbagai bentuk investasi secara efektif maupun usaha pengumpulan dana untuk pembiayaan investasi atau pembelanjaan secara efisien. Sedangkan Menurut James Van Horne "Manajemen Keuangan adalah segala aktivitas yang berhubungan dengan perolehan, pendanaan dan pengelolaan aktiva dengan tujuan menyeluruh". Dapat disimpulkan bahwa kiat manajemen keuangan adalah seni atau cara melakukan segala aktifitas yang berhubungan dengan perolehan, pendanaan dan pengelolaan aktiva dalam berbagai bentuk investasi secara efektif dengan tujuan menyeluruh. Krisis (dari bahasa

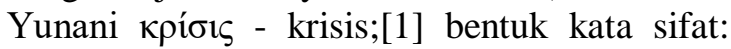
"kritis") adalah setiap peristiwa yang sedang 


\section{Loyalitas Kreativitas \\ Aldi Masyarakat Kreatif}

P-ISSN 2722-2101, E-ISSN 2722-4201

Program Studi Ekonomi Manajemen Universitas Pamulang Jurnal LOKABMAS Kreatif Vol. 01, No. 03, Hal. 106-111

Email:jurnalkreatif.manajemen@gmail.com terjadi (atau diperkirakan) mengarah pada situasi tidak stabil dan berbahaya yang memengaruhi individu, kelompok, komunitas, atau seluruh masyarakat. Krisis dianggap membawa perubahan negatif dalam urusan keamanan, ekonomi, politik, sosial, atau lingkungan, terutama ketika krisis terjadi tibatiba, dengan sedikit atau tanpa peringatan. Lebih jauh, krisis adalah istilah yang berarti "waktu pengujian" atau "peristiwa darurat".

Pandemi COVID-19 adalah peristiwa menyebarnya Penyakitkoronavirus

2019 (bahasa Inggris: coronavirus disease 2019, singkatan dari COVID-19) di seluruh dunia. Penyakit ini disebabkan oleh koronavirus jenis baru yang diberi nama SARS-CoV-2. ${ }^{[2]}$ Wabah COVID-19

pertama kali dideteksi di Kota Wuhan, Provinsi Hubei, Tiongkok pada tanggal 1 Desember 2019, dan ditetapkan sebagai pandemi oleh Organisasi Kesehatan Dunia (WHO) pada tanggal 11 Maret 2020. Hingga 17 September 2020, lebih dari 29.864.555 orang kasus telah dilaporkan lebih dari 210 negara dan wilayah seluruh dunia, mengakibatkan lebih dari 940.651 orang meninggal dunia dan lebih dari 20.317.519 orang sembuh.

\section{HASIL DAN PEMBAHASAN}

Berdasarkan wawancara, tanya jawab dan pengamatan langsung selama kegiatan berlangsung, kegiatan pengabdian pada masyarakat ini memberikan hasil sebagai berikut :

a. Meningkatnya pengetahuan dan pemahaman para remaja khususnya remaja putri peserta didik Rumah Pintar Tangerang Selatan tentang kiat manajemen keuangan dalam menghadapi krisis atau situasi yang tidak terduga seperti pada Pandemi Covid19.

b. Meningkatnya keterampilan para remaja khususnya remaja putri peserta didik Rumah Pintar Tangerang Selatan dalam membuat anggaran rumah tangga.

Beberapa faktor yang mendukung terlaksananya kegiatan pengabdian pada masyarakat ini adalah kerjasama yang baik dari Ketua Rumah Pintar dan para remaja peserta didik Rumah Pintar Tangerang Selatan selama kegiatan, sehingga kegiatan berlangsung dengan lancar dan efektif. Sedangkan faktor penghambatnya adalah kurang antusiasnya para remaja membuat catatan dalam pembelajaran membuat anggaran, keterbatasan waktu pelatihan dan fasilitas peralatan yang minim.

\section{KESIMPULAN DAN SARAN Kesimpulan}

Dari kegiatan pengabdian pada masyarakat ini dapat disimpulkan bahwa:

1. Pengetahuan dan pemahaman para remaja khususnya remaja putri peserta didik Rumah Pintar Tangerang Selatan menjadi meningkat

2. Keterampilan para remaja khususnya remaja putri peserta didik Rumah Pintar Tangerang Selatan dalam membuat anggaran rumah tangga semakin meningkat.

\section{Saran}

Mengingat besarnya manfaat kegiatan pengabdian pada masyarakat ini, maka selanjutnya perlu:

1. Mengadakan sosialisasi dan pelatihan serupa pada para remaja di daerah lain.

2. Adanya kesinambungan program pasca kegiatan pengabdian ini sehingga para remaja khususnya remaja putri peserta didik Rumah Pintar Tangerang Selatan benar-benar dapat mempraktekkan kiat manajemen keuangan dalam menghadapi krisis atau situasi tidak terduga seperti pada saat pandemic Covid-19.

\section{DAFTAR PUSTAKA}

Ardyansah Vedyana; 30 Juni 2020; Ibu Rumah Tangga Berpotensi Alami Stres saat Pandemi Covid19;https://www.ayosemarang.com/read/ 2020/06/30/59519/ibu-rumah-tanggaberpotensi-alami-stres-saat-pandemi-covid19; Unduh Jum'at 04 September 2020 


\section{Loyalitas Kreativitas \\ Aldi Masyarakat Kreatif}

P-ISSN 2722-2101, E-ISSN 2722-4201

Program Studi Ekonomi Manajemen Universitas Pamulang Jurnal LOKABMAS Kreatif Vol. 01, No. 03, Hal. 106-111 Email:jurnalkreatif.manajemen@gmail.com
Daniel: Kumpulan Definisi atau Pengertian Manajemen Keuangan Menurut Para Ahli; https://ekonomimanajemen.com/pengertianmanajemen-keuangan-menurut-para-ahli/; Unduh Sabtu 07 September 2020

Ensiklopedia Bebas Wikipedia; 04 Desember 2019; Krisis; https://id.wikipedia.org/wiki/Krisis; Unduh Sabtu 07 September 2020

Ensiklopedia Bebas Wikipedia; 06 November 2020; Pandemi Covid 19; https://id.wikipedia.org/wiki/Pandemi COVID -19; Unduh Senin 09 Neovember 2020

ID GridHype; Rabu, 26 Agustus 2020; Di Tengah Pandemi Covid-19 Sangat Penting Adanya Perencanaan Keuangan; https://hype.grid.id/read/432308154/di-tengahpandemi-covid-19-sangat-penting-adanyaperencanaan-keuangan?page=all; Unduh, Sabtu 07 September 2020

Indonesia Xdana Investa PT; 2019 ;Bagaimana Cara Mengatur Keuangan Rumah Tangga yang Baik Saat Corona?; https://xdana.com/artikel/bagaimana-caramengatur-keuangan-rumah-tangga-yang-baiksaat-corona/ ; Unduh Jum'at 04 September 2020

Jatmiko Bambang P.; 02 Agustus 2020; Hindari Nambah Utang Di Tengah Pandemi, Yuk Mulai Terapkan 4 Kebiasaan Ini; https://money.kompas.com/read/2020/08/02/0 90800426/hindari-nambah-utang-di-tengahpandemi-yuk-mulai-terapkan-4-kebiasaanini?page $=$ all; Unduh Jum'at 04 September 2020

Kamus Besar Bahasa Indonesia (KBBI).Kamus versi online/daring (dalam jaringan);Kiat; https://kbbi.web.id/kiat-2; Unduh Sabtu 07 September 2020

Kompas.com; 24 Juni 2020; 4 Perusahaan Startup Lakukan PHK Akibat Covid-19, Apa Saja ?; https://money.kompas.com/read/2020/06/24/1 32517726/4-perusahaan-startup-lakukan-phk- akibat-covid-19-apa-saja; Unduh Senin 07 September 2020

Kompas.com; 08 Juli 2020; Krisis akibat Covid-19 73 Perusahaan di 8.282 Karyawan; https://megapolitan.kompas.com/read/2020/07/ $\underline{08 / 20080591 / k r i s i s-a k i b a t-c o v i d-19-73-}$ perusahaan-di-kota-tangerang-phk-8282karyawan; Unduh Senin 07 September 2020

Lenteratoday.com; 20 Mei 2020; Atur Keuangan Saat Pandemi, Bedakan Kebutuhan \& Keinginan; https://lenteratoday.com/atur-keuangan-saatpandemi-bedakan-kebutuhan-keinginan/; Rabu, Unduh Jum'at 04 september 2020

Novianti Leny, Denziana Angrieta; Manajemen Keuangan Keluarga; ;http://ejournal.uin-

suska.ac.id/index.php/marwah/article/view/481 ; Vol 9, No 2; (2010); http://dx.doi.org/10.24014/marwah.v9i2.481; Unduh Senin 07 September 2020 DOI:

Novrita; Membuat Pos Anggaran Sendiri; 26 Juni 2015; https://www.kompasiana.com/novri/55009221 a333111e7351151c/membuat-pos-anggaransendiri; Unduh Jum'at 04 September 2020

Oktrima, B., Tumanngor, M., Jati, W., Wartono, T., \& Sari, A. R. (2020). PENGELOLAAN KEUANGAN KELUARGA PADA KELOMPOK PENGAJIAN IBU-IBU SEKELURAHAN PAMULANG BARAT TANGERANG SELATAN. Jurnal ABDIMAS Tri Dharma Manajemen, 1(2).

Pasaribu, V. L. D., Susanti, F., \& Hartuti, E. T. K. (2019). Memotivasi Siswa dan Siswi SMK Letris Indonesia di Dalam Menentukan Pilihan Untuk Melanjutkan Pendidikan Atau Bekerja Setelah Lulus Sekolah. Jurnal Pengabdian Dharma Laksana, 1(2), 161-172.

Pasaribu, V. L. D., Elburdah, R. P., Sudarso, E., \& Fauziah, G. (2020). PENGGUNAAN MANAJEMEN WAKTU TERHADAP PENINGKATAN PRESTASI 


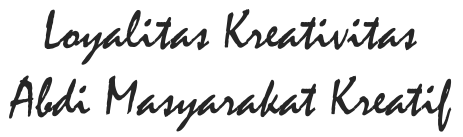

Loyalitas Kreativitas

Aldi Masyarakat Kreatif
P-ISSN 2722-2101, E-ISSN 2722-4201

Program Studi Ekonomi Manajemen Universitas Pamulang Jurnal LOKABMAS Kreatif Vol. 01, No. 03, Hal. 106-111 Email:jurnalkreatif.manajemen@gmail.com
BELAJAR DI SMP ARAISIYAH. Jurnal ABDIMAS Tri Dharma Manajemen, 1(1).

Pasaribu, V. L. D., Agrasadya, A., Shabrina, N., \& Krisnaldy, K. (2020). MENJADI ENTERPRENEUR MUDA YANG MEMILIKI JIWA LEADERSHIP UNTUK MENGHADAPI MASA DEPAN. Abdi Laksana, 1(1).

Pasaribu, V. L. D., Sulaiman, S., Sutiman, S., Thaharudin, T., \& Purnomo, B. Y. (2020). PENGENALAN LETAK POSYANDU TERDEKAT DIKELURAHAN PISANGAN DENGAN MANAJEMEN PEMASARAN REVOLUSI 4.0 UNTUK MENINGKATKAN PENGETAHUAN MASYARAKAT LETAK DAN FUNGSI POSYANDU TERDEKAT PADA KELURAHAN PISANGAN. DEDIKASI PKM, 1(1), 105-110.

Priadi, A., Pasaribu, V. L. D., Virby, S., Sairin, S., \& Wardani, W. G. (2020). PENGUATAN EKONOMI KREATIF BERBASIS SUMBER DAYA DESA DIKELURAHAN REMPOA. Abdi Laksana, 1(3), 356-358

Pranita Ellyvon; 11 Mei 2020; Diumumkan Awal Maret, Ahli: Virus Corona Masuk Indonesia dari Januari; https://www.kompas.com/sains/read/2020/05/1 1/130600623/diumumkan-awal-maret-ahli-virus-corona-masuk-indonesia-dari-januari; Unduh Jum'at 04 September 2020

Rara Radhita; 09 Mei 2020;Selama Pandemi, Deretan Hobi Ini Bisa Jadi Ladang Penghasilan, lho!; https://journal.sociolla.com/lifestyle/hobi-jadipenghasilan-selama-pandemi; Unduh Jum'at 04 September 2020

Rizki Mochammad Januar Sabtu 30 Mei 2020;; Hati-hati Jeratan Pinjaman Online Berkedok Koperasi di Tengah Pandemi Covid-19; https://www.hukumonline.com/berita/baca/lt5e d1da913f7e7/hati-hati-jeratan-pinjaman- online-berkedok-koperasi-di-tengah-pandemicovid-19/; Unduh Jum'at 04 September 2020

Salirawati Das; 2004; Manajemen Kuangan Keluarga;

http://staffnew.uny.ac.id/upload/132001805/pe ngabdian/14manajemen-keuangan-

keluarga.pdf; Unduh Senin 07 September 2020

Silvy Meliza, Yulianti Norma; Sikap Pengelola Keuangan dan PEerilaku Perencanaan InvestasiI Keluarga Di Surabaya; https://journal.perbanas.ac.id/index.php/jbb/art icle/view/254; Vol 3, No 1 (2013); DOI: http://dx.doi.org/10.14414/jbb.v3i1.254 ; Unduh Senin 07 September 2020

Tambunan Liza; 19 April 2020; Dampak sosial virus corona: Beban 'berlipat ganda' bagi perempuan di masa pandemi Covid-19; https://www.bbc.com/indonesia/indonesia52323527; Unduh Jum'at 04 September 2020

Theasianparent.com; Jangan sampai salah ! Begini cara kelola keuangan saat pandemic Covid-19;

https://id.theasianparent.com/manajemenkeuangan-rumah-tangga; Unduh Kamis, 03 September 2020

Unitedtronik; 09 Oktober 2019; 6 TIPS MEMBUAT ANGGARAN RUMAH TANGGA BULANAN YANG MUDAH DILAKUKAN SEKARANG JUGA; https://blog.unitedtronik.co.id/membuatanggaran-rumah-tangga/;Unduh Jumat 04 September 2020

Zuraya Nidia; Selasa 26 Mei 2020; Pandemi Covid-19 Berdampak pada Keuangan Rumah Tangga; https://republika.co.id/berita/qaxays383/pande mi-covid19-berdampak-pada-keuanganrumah-tangga; Unduh Jum'at 04 September 2020

DOKUMENTASI KEGIATAN 


\section{Loyalitas Kreativitas \\ P-ISSN 2722-2101, E-ISSN 2722-4201}

Aldi Masyarakat Kreatif
Program Studi Ekonomi Manajemen Universitas Pamulang Jurnal LOKABMAS Kreatif Vol. 01, No. 03, Hal. 106-111

Email:jurnalkreatif.manajemen@gmail.com
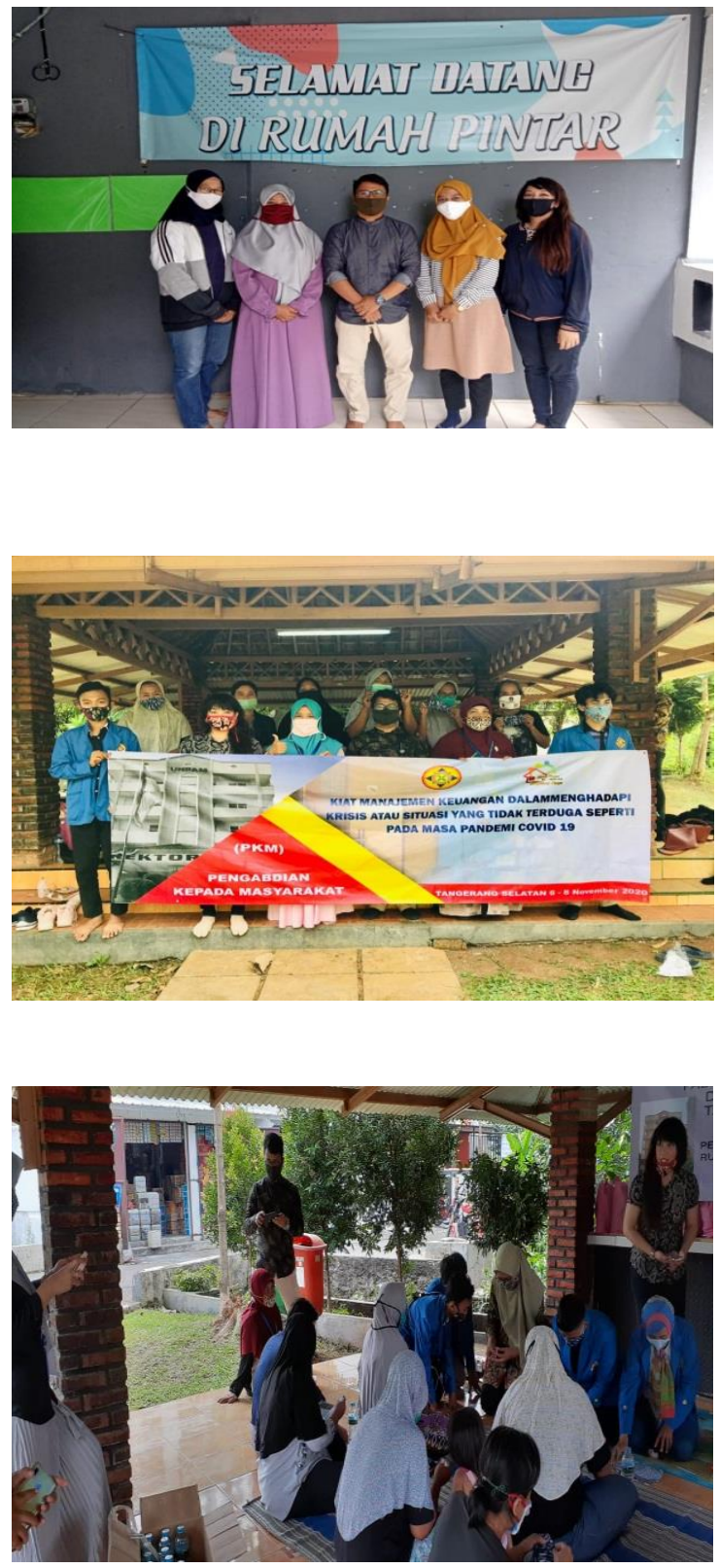